\title{
Faktor Determinan Fungsi Keluarga dan Keintiman Keluarga pada Keluarga Lansia Muslim
}

\author{
Yusuf Alam Romadhon ${ }^{*}$ \\ ${ }^{1}$ Fakultas Kedokteran Universitas Muhammadiyah Surakarta \\ Email: 1yar245@ums.ac.id
}

Tanggal Submisi: 2 April 2021; Tanggal Penerimaan: 27 Agustus 2021

\begin{abstract}
Abstrak
Latar belakang: Fungsi dan keintiman keluarga merupakan faktor protektif dari penyakit fisik, mental, dan menentukan kualitas hidup lansia. Sedikit kajian yang mengeksplorasi faktor determinan yang berpengaruh terhadap kedua faktor tersebut. Tujuan: untuk mengetahui faktor determinan fungsi dan keintiman keluarga pada populasi keluarga Muslim Indonesia. Metode: Sebanyak 106 subyek berkeluarga 40 tahun ke atas berpartisipasi dalam penelitian ini. Faktor yang diuji meliputi usia, tingkat pendidikan, jenis kelamin, pendapatan, IMT, RLPP, tekanan darah, tingkat depresi, anxietas stres, jumlah rakaat sholat, fungsi keluarga dan keintiman keluarga. Hasil: Faktor usia berkorelasi dengan keintiman seksual $(\mathrm{r}=-0,269 ; \mathrm{p}=0,005)$, intelektual $(\mathrm{r}=0,332 ; \mathrm{p}=0,001)$, rekreasional $(\mathrm{r}=-0,303 ; \mathrm{p}=0,002)$; tekanan diastolik dengan keintiman seksual $(r=0,227 ; p=0,019)$, jumlah rakaat sholat dengan keintiman emosional $(r=0,204$; $\mathrm{p}=0,036)$. Faktor yang berkorelasi dengan fungsi keluarga meliputi tingkat depresi, anxietas dan stress, secara berurutan nilai [r;p]: $r=-0,224 ; \mathrm{p}=0,021, \mathrm{r}=$ $-0,285 ; \mathrm{p}=0,003, \mathrm{r}=-0,236 ; \mathrm{p}=0,015$; IMT $(\mathrm{r}=-0,209 ; \mathrm{p}=0,032)$;. Kesimpulan: faktor determinan keintiman keluarga meliputi usia (korelasi negatif), tekanan diastolic, jumlah rakaat sholat (korelasi positif); faktor determinan fungsi keluarga meliputi IMT dan status mental (korelasi negatif).
\end{abstract}

Kata kunci : Faktor determinan, fungsi keluarga, keintiman keluarga.

\section{ABSTRACT}

Background: Family function and intimacy are protective factors against physical, mental illness, and determine the quality of life of the elderly. Few studies have explored the determinant factors that influence these two factors. Objective: to determine the determinants of family function and intimacy in the Indonesian Muslim family population. Methods: A total of 106 subjects with families 40 years and over participated in this study. The factors tested included age, education level, gender, income, BMI, waist to hip ratio (WtHR), blood pressure, depression, anxiety and stress levels, number of rakats of prayer, family function and family intimacy. Results: Age was correlated with sexual intimacy $(r=-0,269 ; p=0,005)$, intellectual $(r=-0,332 ; p=0,001)$, recreational $(r=0.303 ; \quad p=0.002) ;$ diastolic pressure with sexual intimacy $(r=0.227$; $p=0.019)$, the number of rakaats of prayer with emotional intimacy $(r=0.204$; $p=0.036)$. Factors that correlate with family function include levels of depression, anxiety and stress, respectively the value [r;p]: $r=-0,224$; 
$p=0,021, r=-0,285 ; p=0,003, r=-0,236 ; p=0,015 ;$ BMI $(r=-0,209 ; p=$ 0,032);. Conclusion: determinants of intimacy include age (negative correlation), diastolic pressure and number of rak'ahs of prayer (positive correlation); determinants of family function include BMI and psychological status (negative correlation).

Keywords: Determinant factors, family function, family intimacy,

ISSN 1979-7621 (Print). ISSN 2620-7761 (Online)

DOI 10.23917/jk.v14i2.13620

\section{PENDAHULUAN}

Pernikahan adalah hubungan timbal balik antara suami istri yang bersatu dalam suatu hubungan ketergantungan khusus dan legal untuk menegakkan dan memelihara keluarga (Zakhirehdari et al., 2019). Kebersatuan ini merupakan komitmen hubungan jangka panjang yang stabil, di mana hubungan ini bisa terancam dari berbagai jalur yang menyebabkan ketidakstabilan pernikahan (Czyżkowska \& Cieciuch, 2020). Ketidakstabilan pernikahan digambarkan sebagai situasi di mana pasangan yang menikah belum bercerai atau berpisah dalam pernikahan mereka, tetapi karena berbagai alasan mempunyai kecenderungan untuk berpisah (Mousavi, 2016). Keluarga merupakan institusi sosial yang paling dekat, penting, dan bermakna bagi setiap orang sejak awal kehidupan mereka. Keluarga juga merupakan lembaga sosial dasar yang membentuk pola kepribadian, gagasan, keyakinan, sikap dan perilaku. Perilaku baik positif maupun negatif anggota keluarga menjadi dasar sekaligus berperan penting dalam membentuk keberhasilan maupun kegagalan seseorang. Ketika anggota keluarga menunjukkan kehangatan, kasih sayang dan kepedulian, memberikan konseling dan nasihat, keintiman, terbentuknya sikap timbal balik, serta individu merasa dicintai dan dibutuhkan, menerima cinta dan kepedulian dari orang tua atau pengasuh utamanya akan memungkinkan anak dapat tumbuh dan berkembang di semua aspeknya secara baik (Sitsira-at, 2019).

Keluarga merupakan suatu sistem sosial, di mana sistem ini akan memberikan keberfungsiannya untuk memberikan respons adaptif terhadap perubahan-perubahan yang dialami oleh masing-masing anggotanya, melebihi dari peran "struktural" masingmasing anggota dalam keluarga (Schoors et al., 2017). Fungsi keluarga mengukur seberapa besar keluarga sebagai gabungan [komposit] bekerja sebagai suatu kesatuan; kerja ini ditunjukkan dari kemampuannya melakukan koping dan menyesuaikan di berbagai situasi yang terangkum dalam 5 komponen: adaptasi [adaptation], kemitraan [partnership], pertumbuhan [growth], afeksi [affection], dan kebersamaan [resolve] (Panganiban-Corales \& Medina, 2011). Fungsi keluarga merupakan ekspresi efikasi kolektif untuk bekerja secara bersama dalam mempromosikan perkembangan dan kesejahteraan masing-masing anggota, mempertahankan ikatan kemanfaatan dengan sistem di luar keluarga dalam mewujudkan ketahanan serta kesigapan untuk pulih (Procentese et al., 2019). Setiap anggota keluarga pada hakikatnya merupakan bagian dari subsistem keluarga tersebut. Adaptasi yang efektif dalam perbedaan latar belakang antar anggota keluarga pada pernikahan multi-budaya, berkorelasi positif dengan perilaku kesehatan yang baik (J. Y. Lee et al., 2019). Keberadaan sakit terutama penyakit katastrofik pada salah satu anggota keluarga 
akan mengganggu kontribusi anggota keluarga tersebut serta merupakan beban adaptif terhadap keberfungsian keluarga, penyesuaian pernikahan, adaptasi psikologis serta keintiman keluarga (Melisko et al., 2010)(Brandão et al., 2017). Gangguan kontribusi tersebut dapat berupa distres akibat sakit, berkurangnya kemandirian dan kesejahteraan sosial, "hilangnya" fungsi organ yang menunjang salah satu keintiman [organ seksual primer maupun sekunder akibat tindakan terapi kanker atau karena proses penuaan seperti menopause], disfungsi seksual akibat gangguan tidur dan berbagai kondisi lain yang melemahkan (Warner et al., 2016).

Keintiman merupakan persepsi seseorang mengenai keterhubungan atau kebersatuan dirinya dengan pasangan ataupun keluarganya (Martyn et al., 2009). Keintiman tidak saja berlaku pada pasangan, tetapi juga dalam konteks hubungan orang tua - anak. Keintiman ini meliputi aspek emosional, seksual, rekreasional, intelektual dan hubungan orang tua anak (Czyżowska et al., 2019)(Rizkalla \& Segal, 2019). Keintiman merupakan faktor kunci yang berkontribusi pada kesejahteraan fisik dan psikologis, faktor protektif dari perilaku berisiko, kepuasan pernikahan, kualitas pernikahan, stabilitas pernikahan, dan keberfungsian pernikahan (Kuczynski et al., 2020)(Kamali et al., 2020). Keintiman pernikahan mempunyai pengaruh positif pada berbagai aspek outcome secara individu maupun bagi anak, meliputi kepengasuhan orang tua-anak serta dukungan pada anak, dukungan pasangan serta kesadaran pengasuhan pada lanjut usia, juga pada kesehatan fisik maupun psikologis pada kelompok lanjut usia (Brower et al., 2019)(Do et al., 2019)(Karimi et al., 2019). Kondisi sebaliknya, ketidakintiman berkorelasi dengan ketidakpuasan dalam pengalaman hubungan dan hubungan seksualitas (Javadivala et al., 2019). Keintiman dan dukungan keluarga mempunyai pengaruh pada kepatuhan penderita terhadap intervensi medik dan perilaku sehat (Trief et al., 2002)(Kuo et al., 2007). Keyakinan seseorang untuk "mampu menguasai" permasalahan yang dihadapi yang merupakan dampak dari bantuan keluarga pada adaptasi anggota keluarganya dalam menghadapi permasalahan yang dihadapi, merupakan bagian integral dari fungsi keluarga (Busari, 2019). Penurunan keintiman pernikahan dapat mengganggu keberfungsian keluarga, durasi dan kelestarian pernikahan (Asgari \& Goodarzi, 2019). Karena peran pentingnya tersebut, maka dalam perspektif pencegahan penyakit, keluarga mempunyai andil besar dalam membentuk pengalaman sehat masing-masing anggota sejak dini, membentuk pola perilaku yang dapat membuat seseorang rentan mengalami penyakit atau sebaliknya protektif terhadap penyakit di kemudian hari (Davison et al., 2013).

Lanjut usia mempunyai kondisi rentan untuk mengalami penyakit katastrofi yang dapat mempengaruhi keintiman dengan keluarga dan pasangan mereka. Lebih lanjut keadaan ini mempengaruhi kualitas hidup pasien, pasangan dan keluarganya (Kraemer et al., 2011)(Wang et al., 2013). Wanita lanjut usia, selain mengalami proses biologis alami menopause dan berbagai penurunan fisiologis tubuh, juga didapatkan kecenderungan menderita penyakit katastrofi, yang lebih lanjut akan mempengaruhi kualitas hidup mereka (Chintya et al., 2019). Penurunan kualitas hidup ini juga mempengaruhi keintiman dengan pasangan mereka serta kontribusi mereka dalam fungsi keluarga (Schofield et al., 2013). Bagi mereka yang sudah berkeluarga, kesehatan mental secara pribadi lebih merupakan pengaruh dari kehidupan pernikahan dan keluarga mereka (Vincent, 1986). Anxietas dan depresi mempengaruhi fungsi seksual pada wanita, atau dapat dikatakan bahwa disfungsi seksual wanita dipengaruhi oleh anxietas dan depresi. Individu yang terpengaruhi oleh aktivitas online dan pengguna konten seksual secara online mempengaruhi kualitas hubungan seksual dengan pasangannya (Alimoradi et al., 2019). Kualitas perkawinan mempunyai pengaruh pada keterkendalian kadar gula pada penderita diabetes serta kualitas hidup mereka (Trief et al., 2001). 


\section{METODE PENELITIAN}

Penelitian ini merupakan penelitian analitik dengan pendekatan potong lintang. Subyek penelitian direkrut dengan metode cluster random sampling, melalui pemilihan posyandu lansia di 14 desa di Kecamatan Gatak Sukoharjo dalam periode waktu bulan November - Desember 2019. Sebanyak 106 subyek yang berhasil direkrut, merupakan peserta posyandu lansia dengan rentang usia $40-90$ tahun [rerata $=63.3$ tahun], berkeluarga dan beragama Islam. Setiap subyek penelitian diberikan kuesioner yang berisi pertanyaan usia, jenis kelamin, pendidikan, pendapatan, dan status pernikahan. Kuesioner depression anxiety stress scale 21 pertanyaan berbahasa Indonesia, diberikan untuk mengukur tingkat depresi, anxietas, dan stres. Keintiman keluarga diukur menggunakan kuesioner keintiman keluarga Muchlas - Sudiyanto, sedangkan fungsi keluarga diukur menggunakan APGAR family berbahasa Indonesia. Keintiman keluarga mempunyai 5 dimensi yakni keintiman emosional, seksual, intelektual, rekreasional dan hubungan orang tua - anak. Subyek diukur berat badan dan tinggi badan untuk dihitung indeks masa tubuh mereka, tekanan darah, dan lingkar pinggang dan panggul untuk dihitung rasio lingkar pinggang/ panggul (RLPP). Analisis hubungan dilakukan dengan analisis korelasi bivariat untuk data tidak normal (Spearman).

\section{HASIL DAN PEMBAHASAN}

Dari Tabel 1, terlihat bahwa sebagian besar responden dalam penelitian ini termasuk lanjut usia, didominasi perempuan, berpendidikan kurang dari 12 tahun, sebagian besar berpendapatan di bawah upah minimun regional. Seluruh responden berstatus menikah, sebagian besar normoweight, normotensi, tingkat depresi, anxietas dan stress masuk dalam kategori normal, serta memenuhi jumlah rakaat minimal dalam agama Islam. Tabel $\mathbf{2}$ merupakan karakteristik responden penelitian dalam skala kontinu.

Tabel 1. Karakteristik responden penelitian (skala kategorik; $n=106$ )

\begin{tabular}{llrr}
\hline Variabel & Kategori & n & \% \\
\hline Usia & Pra lanjut usia & 41 & 39 \\
Gender & Lanjut usia & 65 & 61 \\
& Perempuan & 82 & 77 \\
Pendidikan & Laki-laki & 24 & 23 \\
Pendapatan & 12 tahun lebih & 28 & 26 \\
& L12 tahun & 78 & 74 \\
Status pernikahan & UMR ke atas & 34 & 32 \\
\multirow{3}{*}{ Body mass index } & bawah UMR & 72 & 68 \\
& Menikah & 106 & 100 \\
Rasio lingkar pinggang/panggul & Tidak menikah & 0 & 0 \\
\multirow{2}{*}{ Tekanan darah } & Normal & 67 & 63 \\
& Overweight/obese & 39 & 37 \\
Depresi & Normal & 22 & 21 \\
& Obesitas sentral & 84 & 79 \\
Ansietas & Normotensi & 68 & 64 \\
\multirow{2}{*}{ Stres } & Hipertensi & 38 & 36 \\
& Normal & 95 & 90 \\
Fungsi keluarga & Depresi & 11 & 10 \\
Jumlah rakaat sholat harian & Normal & 99 & 93 \\
& Anxietas & 7 & 7 \\
& Normal & 101 & 95 \\
& Stres & 5 & 5 \\
& Baik & 88 & 83 \\
& Buruk & 18 & 17 \\
& Cukup & 97 & 92 \\
& Kurang & 9 & 8 \\
\hline
\end{tabular}


Tabel 2. Karakteristik responden penelitian (skala kontinu; N=106)

\begin{tabular}{lllll}
\hline Variabel & Rata-rata & SD & Min & Max \\
\hline Usia (tahun) & 63 & 11 & 40 & 90 \\
Pendapatan (Rupiah) & 1470623 & 1475986 & 200000 & 9000000 \\
BMI (kg BB/m² TB) & 23,71 & 4,84 & 13,00 & 39,00 \\
RLPP & 0,88 & 0,09 & 0,47 & 1,23 \\
Sistol (mmHg) & 136,94 & 19,35 & 90,00 & 197,00 \\
Diastol (mmHg) & 81,21 & 10,99 & 60,00 & 110,00 \\
Depresi & 4,68 & 0,00 & 4,68 & 34,00 \\
Anxietas & 3,00 & 0,00 & 3,00 & 19,00 \\
Stress & 3,43 & 0,00 & 3,43 & 20,00 \\
Jumlah rakaat & 8,72 & 0,00 & 8,72 & 35,00 \\
\hline
\end{tabular}

Tabel 3 merupakan hasil dari analisis bivariat yang mengkorelasikan berbagai faktor determinan dengan fungsi keluarga dan keintiman keluarga. Faktor determinan yang dianalisis meliputi pendapatan, usia, indeks masa tubuh, rasio pinggang/ pinggul, tekanan darah sistol dan diastol, tingkat depresi, anxietas, stress serta jumlah rakaat sholat yang dilakukan dalam sehari semalam.

Dari Tabel 3 didapatkan bahwa, usia berkorelasi negatif dengan keintiman seksual $(\mathrm{r}=-0,269 ; \mathrm{p}=0,005)$, intelektual $(\mathrm{r}=-0,332$; $\mathrm{p}=0,001)$, dan rekreasional $(\mathrm{r}=-0,303$; $\mathrm{p}=0,002$ ). Indeks masa tubuh berkorelasi negatif dengan fungsi keluarga $(r=-0,209$; $\mathrm{p}=0,032)$. Tekanan diastolik berkorelasi positif dengan keintiman seksual $(\mathrm{r}=0,227$; $\mathrm{p}=0,019)$. Tingkat depresi, anxietas dan stres berkorelasi negatif dengan fungsi keluarga, secara berurutan nilai $[\mathrm{r} ; \mathrm{p}]=\mathrm{r}=-0,224 ; \mathrm{p}=$ $0,021, \quad r=-0,285 ; p=0,003, \quad r=-0,236$; $\mathrm{p}=0,015$. Jumlah rakaat sholat berkorelasi positif dengan keintiman emosional $(\mathrm{r}=0,204$; $\mathrm{p}=0,036$ ).

Temuan dari penelitian ini usia berkorelasi negatif dengan keintiman seksual, intelektual, dan rekreasional. Dari temuan ini dapat dikatakan bahwa semakin lanjut usia seseorang, semakin menurun persepsi tentang keintiman seksual, intelektual maupun rekreasionalnya. Baik pria maupun wanita, dengan makin lanjutnya usia, terdapat penurunan aktivitas dan hasrat seksual (Štulhofer et al., 2020). Kemungkinan faktor tersebut yang menyebabkan penurunan keintiman seksual, intelektual dan rekreasional.

Temuan dari faktor biologis lainnya yakni, indeks masa tubuh berkorelasi negatif dengan fungsi keluarga dan tekanan diastolik berkorelasi positif dengan keintiman seksual. Dari temuan ini dapat dikatakan bahwa semakin besar indeks masa tubuh akan menurunkan persepsi fungsi keluarga seseorang. Kondisi fisik yang kurang dalam kepustakaan, seperti 'telah mengetahui bahwa dirinya berstatus karier gen BRCA1' dapat menurunkan persepsi keberfungsian dirinya pada keluarganya (Stroup \& Smith, 2007). Anak dari orang tua yang menderita penyakit kronik didapatkan lebih berisiko mengalami gangguan mental seperti depresi dan anxietas dibandingkan populasi lainnya (Sieh et al., 2013). Dari temuan kedua dapat dikatakan bahwa tekanan darah diastolik berkorelasi positif dengan persepsi tentang keintiman seksual seseorang (kekuatan korelasi lemah). 
Tabel 3. Analisis bivariat berbagai faktor determinan terhadap fungsi keluarga dan keintiman keluarga

\begin{tabular}{|c|c|c|c|c|c|c|}
\hline \multirow{2}{*}{$\begin{array}{l}\text { Faktor } \\
\text { determinan }\end{array}$} & \multirow{2}{*}{$\begin{array}{l}\text { Fungsi } \\
\text { keluarga }\end{array}$} & \multicolumn{5}{|c|}{ Keintiman } \\
\hline & & Emosional & Seksual & Intelektual & $\begin{array}{c}\text { Rekreasi- } \\
\text { onal }\end{array}$ & $\begin{array}{c}\text { Ortu - } \\
\text { anak }\end{array}$ \\
\hline Pendapatan & $\begin{array}{l}r=0,010 \\
p=0,917\end{array}$ & $\begin{array}{l}r=0,178 \\
p=0,068\end{array}$ & $\begin{array}{l}r=0,183 \\
p=0,060\end{array}$ & $\begin{array}{l}r=0,142 \\
p=0,147\end{array}$ & $\begin{array}{l}r=0,181 \\
p=0,063\end{array}$ & $\begin{array}{l}r=0,108 \\
p=0,270\end{array}$ \\
\hline Usia & $\begin{array}{l}r=0,021 \\
p=0,827\end{array}$ & $\begin{array}{l}r=-0,157 \\
p=0,109\end{array}$ & $\begin{array}{l}r=-\mathbf{0 , 2 6 9} \\
p=\mathbf{0 , 0 0 5}\end{array}$ & $\begin{array}{l}r=-\mathbf{0 , 3 3 2} \\
p=\mathbf{0 , 0 0 1}\end{array}$ & $\begin{array}{l}r=-\mathbf{0 , 3 0 3} \\
p=\mathbf{0 , 0 0 2}\end{array}$ & $\begin{array}{l}r=-0,157 \\
p=0,108\end{array}$ \\
\hline IMT & $\begin{array}{l}r=-\mathbf{0 , 2 0 9} \\
p=\mathbf{0 , 0 3 2}\end{array}$ & $\begin{array}{l}r=-0,038 \\
p=0,701\end{array}$ & $\begin{array}{l}r=0,032 \\
p=0,741\end{array}$ & $\begin{array}{l}r=-0,038 \\
p=0,697\end{array}$ & $\begin{array}{l}r=0,002 \\
p=0,981\end{array}$ & $\begin{array}{l}r=-0,031 \\
p=0,751\end{array}$ \\
\hline $\begin{array}{l}\text { Rasio pinggang / } \\
\text { pinggul }\end{array}$ & $\begin{array}{l}r=0,028 \\
p=0,776\end{array}$ & $\begin{array}{l}r=-0,048 \\
p=0,622\end{array}$ & $\begin{array}{l}r=0,010 \\
p=0,917\end{array}$ & $\begin{array}{l}r=-0,085 \\
p=0,386\end{array}$ & $\begin{array}{l}r=0,085 \\
p=0,386\end{array}$ & $\begin{array}{l}r=0,021 \\
p=0,827\end{array}$ \\
\hline Sistol & $\begin{array}{l}r=-0,072 \\
p=0,464\end{array}$ & $\begin{array}{l}r=-0,024 \\
p=0,805\end{array}$ & $\begin{array}{l}r=0,049 \\
p=0,621\end{array}$ & $\begin{array}{l}r=-0,122 \\
p=0,214\end{array}$ & $\begin{array}{l}r=-0,065 \\
p=0,509\end{array}$ & $\begin{array}{l}r=-0,199 \\
p=0,041\end{array}$ \\
\hline Diastol & $\begin{array}{l}r=0,058 \\
p=0,551\end{array}$ & $\begin{array}{l}r=0,172 \\
p=0,078\end{array}$ & $\begin{array}{l}r=\mathbf{0 , 2 2 7} \\
p=\mathbf{0 , 0 1 9}\end{array}$ & $\begin{array}{l}r=0,089 \\
p=0,365\end{array}$ & $\begin{array}{l}r=0,106 \\
p=0,278\end{array}$ & $\begin{array}{l}r=0,025 \\
p=0,797\end{array}$ \\
\hline Depresi & $\begin{array}{l}r=-\mathbf{0 , 2 2 4} \\
p=\mathbf{0 , 0 2 1}\end{array}$ & $\begin{array}{l}r=0,150 \\
p=0,124\end{array}$ & $\begin{array}{l}r=0,166 \\
p=0,088\end{array}$ & $\begin{array}{l}r=0,116 \\
p=0,236\end{array}$ & $\begin{array}{l}r=-0,001 \\
p=0,991\end{array}$ & $\begin{array}{l}r=0,011 \\
p=0,908\end{array}$ \\
\hline Anxietas & $\begin{array}{l}r=-\mathbf{0 , 2 8 5} \\
p=\mathbf{0 , 0 0 3}\end{array}$ & $\begin{array}{l}r=0,044 \\
p=0,653\end{array}$ & $\begin{array}{l}r=0,136 \\
p=0,164\end{array}$ & $\begin{array}{l}r=-0,003 \\
p=0,976\end{array}$ & $\begin{array}{l}r=-0,056 \\
p=0,570\end{array}$ & $\begin{array}{l}r=0,060 \\
p=0,542\end{array}$ \\
\hline Stress & $\begin{array}{l}r=-\mathbf{0 , 2 3 6} \\
p=\mathbf{0 , 0 1 5}\end{array}$ & $\begin{array}{l}r=0,043 \\
p=0,658\end{array}$ & $\begin{array}{l}r=0,054 \\
p=0,584\end{array}$ & $\begin{array}{l}r=-0,030 \\
p=0,760\end{array}$ & $\begin{array}{l}r=-0,044 \\
p=0,658\end{array}$ & $\begin{array}{l}r=-0,042 \\
p=0,669\end{array}$ \\
\hline $\begin{array}{l}\text { Jumlah rakaat } \\
\text { sholat }\end{array}$ & $\begin{array}{l}r=0,110 \\
p=0,263\end{array}$ & $\begin{array}{l}r=\mathbf{0 , 2 0 4} \\
p=\mathbf{0 , 0 3 6}\end{array}$ & $\begin{array}{l}r=0,181 \\
p=0,064\end{array}$ & $\begin{array}{l}r=0,153 \\
p=0,118\end{array}$ & $\begin{array}{l}r=0,190 \\
p=0,051\end{array}$ & $\begin{array}{l}r=0,001 \\
p=0,991\end{array}$ \\
\hline
\end{tabular}

Dari faktor psikospiritual didapatkan bahwa tingkat depresi, anxietas dan stres berkorelasi negatif dengan fungsi keluarga, serta jumlah rakaat sholat berkorelasi positif dengan keintiman emosional. Dari temuan ini dapat dikatakan bahwa semakin tinggi derajat depresi, anxietas dan stress seseorang akan menurunkan persepsi tentang keberfungsian dirinya dalam keluarganya. Sedangkan jumlah rakaat sholat merupakan aspek religious seseorang akan meningkatkan persepsi keintiman emosional dengan pasangannya. Pada populasi yang sudah menikah, depresi lebih didapatkan pada wanita, serta berkorelasi negatif dengan keintiman pernikahan (S. Lee et al., 2013).

Keintiman seksual merupakan cerminan kepuasan dalam pengalaman dan aktivitas seksual (Neijenhuijs et al., 2019). Keberadaan stresor dengan berbagai sebab seperti kanker meningkatkan rasa tertekan, ketakutan, dan perasaan bersalah sehingga mempengaruhi keintiman emosional maupun seksual
(Christie et al., 2010)(Lindau et al., 2011). Proses keintiman emosional ditopang utamanya oleh kelihaian keterampilan emosional [emotional skillfulness], secara khusus merupakan kemampuan untuk mengidentifikasi dan mengkomunikasikan emosi (Cordova et al., 2005).

Suami pekerja rumah tangga, dalam suatu penelitian di Korea Selatan, didapatkan merupakan mediator terjadinya depresi pada istri melalui dampaknya pada keintiman pernikahan (Choi et al., 2020). Penelitian pada 154 pasien muda dengan kanker payudara, didapatkan bahwa kualitas hidup sub skala kesejahteraan fisik, kesejahteraan sosial, dan kesejahteraan fungsional berkorelasi secara signifikan dengan keintiman pernikahan. Kesejahteraan emosional tidak menunjukkan korelasi yang signifikan (Oh \& Hwang, 2018). Penelitian pada pengungsi Siria, skor PTSD berkorelasi negatif dengan keempat dimensi keintiman keluarga (emosional, intelektual, seksual, dan rekreasional) (Rizkalla \& Segal, 
2019). Pada populasi penderita kanker, didapatkan bahwa kesejahteraan seksual mempunyai pengaruh pada keintiman dan seksualitas (Perz et al., 2013). Pengalaman akan peristiwa traumatik didukung dengan kepuasan pada keluarga masih mempunyai dampak yang sama baik positif maupun negatif dalam hal adaptasi setelah mengalami peristiwa tersebut (Svetina \& Nastran, 2012).

\section{KESIMPULAN}

Faktor determinan yang berpengaruh pada fungsi keluarga adalah IMT dan status mental dengan korelasi negatif. Sedangkan yang berpengaruh pada keintiman keluarga adalah usia (korelasi negatif), tekanan diastolik dan jumlah rakaat sholat (korelasi positif).

\section{UCAPAN TERIMAKASIH}

Penulis mengucapkan terima kasih kepada semua responden penelitian yang telah bersedia mengikuti penelitian ini. Ucapan terimakasih penulis ucapkan kepada kader posyandu dan bidan desa, serta kepala Puskesmas Kecamatan Gatak Kabupaten Sukoharjo yang telah memfasilitasi pertemuan penulis dengan responden.

\section{DAFTAR PUSTAKA}

Alimoradi, Z., Lin, C. Y., Imani, V., Griffiths, M. D., \& Pakpour, A. H. (2019). Social media addiction and sexual dysfunction among Iranian women: The mediating role of intimacy and social support. Journal of Behavioral Addictions, 8(2), 318-325. https://doi.org/10.1556/2006.8.2019.24

Asgari, A., \& Goodarzi, K. (2019). Effectiveness of Emotional Schema Therapy on Marital Intimacy among Couples on the Brink of Divorce. 6(2).

Brandão, T., Pedro, J., Nunes, N., Martins, M. V., Costa, M. E., \& Matos, P. M. (2017). Marital adjustment in the context of female breast cancer: A systematic review. Psycho-Oncology, 26(12), 2019-2029. https://doi.org/10.1002/pon.4432

Brower, N., Payne, P. B., \& Simmons, M. (2019). Measuring the effectiveness of a multiyear multi-county marriage celebration: qualitative findings. Marriage and Family Review, 55(7), 601-618. https://doi.org/10.1080/01494929.2019.1589616

Busari, A. O. (2019). Construction and Development of Perceived Marital Self Efficacy Scale. Advances in Social Sciences Research Journal, 6(8), 144-159. https://doi.org/10.14738/assrj.68.6847

Chintya, S. A., Budihastuti, U. R., \& Adriani, R. B. (2019). Effect of Menopause on Quality of Life: Path Analysis from Ponorogo East Jawa. Indonesian Journal of Medicine, 4(2), 155-164. https://doi.org/10.26911/theijmed.2019.04.02.09

Choi, S. Y., Kim, H. R., \& Myong, J. P. (2020). The mediating effects of marital intimacy and work satisfaction in the relationship between husbands' domestic labor and depressive mood of married working women. International Journal of Environmental Research and Public Health, 17(12), 1-12. https://doi.org/10.3390/ijerph17124547

Christie, K. M., Meyerowitz, B. E., \& Maly, R. C. (2010). Depression and sexual adjustment following breast cancer in low-income Hispanic and non-Hispanic White women. Psycho-Oncology, 19(10), 1069-1077. https://doi.org/10.1002/pon.1661

Cordova, J. V., Gee, C. B., \& Warren, L. Z. (2005). Emotional skillfulness in marriage: Intimacy as a mediator of the relationship between emotional skillfulness and marital 
satisfaction. Journal of Social and Clinical Psychology, 24(2), 218-235. https://doi.org/10.1521/jscp.24.2.218.62270

Czyżkowska, A., \& Cieciuch, J. (2020). Marital goals: Circular value-based model and measurement. Current Psychology, 2011. https://doi.org/10.1007/s12144-02000787-0

Czyżowska, D., Gurba, E., Czyżowska, N., Kalus, A., Sitnik-Warchulska, K., \& Izydorczyk, B. (2019). Selected predictors of the sense of intimacy in relationships of young adults. International Journal of Environmental Research and Public Health, 16(22). https://doi.org/10.3390/ijerph16224447

Davison, K. K., Jurkowski, J. M., Li, K., Kranz, S., \& Lawson, H. A. (2013). A childhood obesity intervention developed by families for families: results from a pilot study. International Journal of Behavioral Nutrition and Physical Activity, 10(3), 1-11. https://doi.org/10.3390/su8060520

Do, H.-Y., Kim, Y.-J., \& Lee, S.-J. (2019). Dual Mediating Effect of spousal support and Child support in the Effects of Marital Intimacy on the spousal Caregiving Awareness. Medico-Legal Update, 19(2), 468. https://doi.org/10.5958/09741283.2019.00221.4

Javadivala, Z., Allahverdipour, H., Kouzekanani, K., Merghati-Khoei, E., Asghari Jafarabadi, M., \& Mirghafourvand, M. (2019). A Randomized Trial of a Relationship-Enhancement Approach in Improving Marital Intimacy in MiddleAged Iranian Couples. Journal of Sex and Marital Therapy, 45(3), 190-200. https://doi.org/10.1080/0092623X.2018.1501447

Kamali, Z., Allahyar, N., Ostovar, S., Alhabshi, S. M. S. bin S. M., \& Griffiths, M. D. (2020). Factors that influence marital intimacy: A qualitative analysis of iranian married couples. Cogent Psychology, 7(1), 1-17. https://doi.org/10.1080/23311908.2020.1771118

Karimi, R., Bakhtiyari, M., \& Masjedi Arani, A. (2019). Protective factors of marital stability in long-term marriage globally: a systematic review. Epidemiology and Health, 41, e2019023. https://doi.org/10.4178/epih.e2019023

Kraemer, L., Stanton, A., Meyerowitz, B., Rowland, J., \& Ganz, P. (2011). A Longitudinal Examination of Couples' Coping Strategies as Predictors of Adjustment to Breast Cancer. Journal of Family Psychology, 25(6). https://doi.org/10.1007/s10943-019-00909-4

Kuczynski, A. M., Kanter, J. W., Wetterneck, C. T., Olaz, F. O., Singh, R. S., Lee, E. B., Stowe, T. J., Mazzucchelli, T. G., Mier-Chairez, J., Maitland, D. W. M., Manbeck, K. E., \& Corey, M. D. (2020). Measuring intimacy as a contextual behavioral process: Psychometric development and evaluation of the Awareness, Courage, and Responsiveness Scale. Journal of Contextual Behavioral Science, 16(February), 199-208. https://doi.org/10.1016/j.jcbs.2019.02.004

Kuo, J. A., Voorhees, C. C., Haythornthwaite, J. A., \& Young, D. R. (2007). Associations between family support, family intimacy, and neighborhood violence and physical activity in urban adolescent girls. American Journal of Public Health, 97(1), 101103. https://doi.org/10.2105/AJPH.2005.072348 
Lee, J. Y., Kim, J. S., Kim, S. S., Jeong, J. K., Yoon, S. J., Kim, S. J., \& Lee, S. M. (2019). Relationship between health behaviors and marital adjustment and marital intimacy in multicultural family female immigrants. Korean Journal of Family Medicine, 40(1), 31-38. https://doi.org/10.4082/kjfm.17.0059

Lee, S., Rhie, S., \& Chae, K. Y. (2013). Depression and marital intimacy level in parents of infants with sleep onset association disorder: A reliminary study on the effect of sleep education. Korean Journal of Pediatrics, 56(5), 211-217. https://doi.org/10.3345/kjp.2013.56.5.211

Lindau, S. T., Surawska, H., Paice, J., \& Baron, S. R. (2011). Communication about Sexuality and Intimacy in Couples Affected by Lung Cancer and their Clinical Care Providers Stacy. Psycho-Oncology, 20(2), 179-185. https://doi.org/10.1002/pon.1787

Martyn, K. K., Loveland-Cherry, C. J., Villarruel, A. M., Gallegos Cabriales, E., Zhou, Y., Ronis, D. L., \& Eakin, B. (2009). Mexican adolescents' alcohol use, family intimacy, and parent-adolescent communication. Journal of Family Nursing, 15(2), 152-170. https://doi.org/10.1177/1074840709332865

Melisko, M. E., Goldman, M., \& Rugo, H. S. (2010). Amelioration of sexual adverse effects in the early breast cancer patient. Journal of Cancer Survivorship, 4(3), 247255. https://doi.org/10.1007/s11764-010-0130-1

Mousavi, S. F. (2016). The Predictive Role of Interpersonal Forgiveness in protecting against Marital Instability in Married Couples. International Journal of Psychology, $10(2)$.

Neijenhuijs, K. I., Hooghiemstra, N., Holtmaat, K., Aaronson, N. K., Groenvold, M., Holzner, B., Terwee, C. B., Cuijpers, P., \& Verdonck-de Leeuw, I. M. (2019). The Female Sexual Function Index (FSFI) - A Systematic Review of Measurement Properties. Journal of Sexual Medicine, 16(5), 640-660. https://doi.org/10.1016/j.jsxm.2019.03.001

Oh, Y. K., \& Hwang, S. Y. (2018). Impact of uncertainty on the quality of life of young breast cancer patients: Focusing on mediating effect of marital intimacy. Journal of Korean Academy of Nursing, 48(1), 50-58. https://doi.org/10.4040/jkan.2018.48.1.50

Panganiban-Corales, A. T., \& Medina, M. F. (2011). Family resources study: Part 1: Family resources, family function and caregiver strain in childhood cancer. Asia Pacific Family Medicine, 10(1), 14. https://doi.org/10.1186/1447-056X-10-14

Perz, J., Ussher, J. M., \& Gilbert, E. (2013). Constructions of sex and intimacy after cancer: Q methodology study of people with cancer, their partners, and health professionals. BMC Cancer, 13(1), 1. https://doi.org/10.1186/1471-2407-13-270

Procentese, F., Gatti, F., \& Di Napoli, I. (2019). Families and social media use: The role of parents' perceptions about social media impact on family systems in the relationship between family collective efficacy and open communication. International Journal of Environmental Research and Public Health, 16(24). https://doi.org/10.3390/ijerph16245006

Rizkalla, N., \& Segal, S. P. (2019). War can harm intimacy: consequences for refugees 
who escaped Syria. Journal of Global Health, 9(2), 020407. https://doi.org/10.7189/jogh.09.020407

Schofield, P., Juraskova, I., Bergin, R., Gough, K., Mileshkin, L., Krishnasamy, M., White, K., Bernshaw, D., Penberthy, S., \& Aranda, S. (2013). A nurse- and peer-led support program to assist women in gynaecological oncology receiving curative radiotherapy, the PeNTAGOn study (Peer and nurse support trial to assist women in gynaecological oncology): Study protocol for a randomised controlled tria. Trials, 14(1), 1-11. https://doi.org/10.1186/1745-6215-14-39

Schoors, M. Van, Caes, L., Alderfer, M. A., Goubert, L., \& Verhofstadt, L. (2017). Couple functioning after pediatric cancer diagnosis: a systematic review. Journal of the Psychological, Social and Behavioral Dimensions of Cancer, 26(5), 608-616.

Sieh, D. S., Visser-Meily, J. M. A., \& Meijer, A. M. (2013). Differential Outcomes of Adolescents with Chronically Ill and Healthy Parents. Journal of Child and Family Studies, 22(2), 209-218. https://doi.org/10.1007/s10826-012-9570-8

Sitsira-at, S. (2019). Risk management in family cohesion. 23(1), 15-31.

Stroup, A. M., \& Smith, K. R. (2007). Familial effects of BRCA1 genetic mutation testing: Changes in perceived family functioning. Cancer Epidemiology Biomarkers and Prevention, 16(1), 135-141. https://doi.org/10.1158/1055-9965.EPI-06-0178

Štulhofer, A., Jurin, T., Graham, C., Janssen, E., \& Træen, B. (2020). Emotional intimacy and sexual well-being in aging European couples: a cross-cultural mediation analysis. European Journal of Ageing, 17(1), 43-54. https://doi.org/10.1007/s10433-019-00509-x

Svetina, M., \& Nastran, K. (2012). Family relationships and post-traumatic growth in breast cancer patients. Psychiatria Danubina, 24(3), 298-306.

Trief, P. M., Himes, C. L., Orendorff, R., \& Weinstock, R. S. (2001). The marital relationship and psychosocial adaptation and glycemic control of individuals with diabetes. Diabetes Care, 24(8), 1384-1389. https://doi.org/10.2337/diacare.24.8.1384

Trief, P. M., Wade, M. J., Britton, K. D., \& Weinstock, R. S. (2002). A prospective analysis of marital relationship factors and quality of life in diabetes. Diabetes Care, 25(7), 1154-1158. https://doi.org/10.2337/diacare.25.7.1154

Vincent, M. O. (1986). A well doctor's family: the struggle for intimacy. Maryland Medical Journal (Baltimore, Md. : 1985), 35(2), 111-115.

Wang, F., Chen, F., Huo, X., Xu, R., Wu, L., Wang, J., \& Lu, C. (2013). A Neglected Issue on Sexual Well-Being following Breast Cancer Diagnosis and Treatment $\begin{array}{llll}\text { among Chinese } \quad \text { Women. } & \text { ONE, }\end{array}$ https://doi.org/10.1371/journal.pone.0074473

Warner, E. L., Kent, E. E., Trevino, K. M., Parsons, H. M., Zebrack, B. J., \& Kirchhoff, A. C. (2016). Social well-being among adolescents and young adults with cancer: A systematic review. Cancer, 122(7), 1029-1037. https://doi.org/10.1002/cncr.29866

Zakhirehdari, N., Navabinejad, S., \& Koraei, A. (2019). Marital Intimacy of Couples. 23(97). 
Y A Romadhon / Jurnal Kesehatan 14 (2) 2021, 149-1 